\title{
Celowość i możliwości obniżenia kosztów nakładania antykorozyjnych powłok metalowo-malarskich natryskiwanych cieplnie
}

\author{
Possibilities and purposefulness of cost reduction \\ in application of thermal sprayed \\ anticorrosive metal-paint coatings
}

\section{Streszczenie}

$\mathrm{Na}$ podstawie analizy doświadczeń krajowych i zagranicznych opisano wpływ zastosowanej metody ochrony konstrukcji przed korozją na tzw. cykl życia obiektu, czyli koszty wykonania powłoki ochronnej i jej konserwacji przez cały przewidziany okres użytkowania obiektu i wynikającą z niej celowość stosowania powłok metalowo-malarskich natryskiwanych cieplnie. Omówiono ustanowione w tym zakresie normy i obowiązujące lub zalecane przepisy krajowe oraz stosowane na ich podstawie technologie. Udowodniono konieczność wprowadzenia w tym zakresie zmian. Opisano wpływ rodzaju zastosowanych urządzeń i kwalifikacji personelu na koszty procesu.

Słowa kluczowe: natryskiwanie cieplne, powłoki antykorozyjne, powłoki metalowo-malarskie

\begin{abstract}
Influence of anticorrosion protection applied on structures on so called life-cycle of an object was analysed on the base of national and international practice including costs of application of thermal sprayed metalpaint coatings and maintenance during whole foreseeable exploitation of an object and resulting purposefulness of thermal sprayed metal-paint coatings. Effective standards and recommended regulations in this area as well as elaborated on their base technologies were discussed. Necessity of changes in this area was proven. Impact of types of used machinery and staff qualifications on the process costs was described.
\end{abstract}

Keywords: thermal spraying, anticorrosive coatings, metal-paints coatings

\section{Wstęp}

Podstawowym wymaganiem stawianym dobrej ochronie przed korozją jest spełnienie przez nią określonych zadań przy możliwie najniższych kosztach. Do zadań tych zalicza się:

- wystarczającą trwałość wybranego systemu ochronnego w warunkach eksploatacji,

- wybrany system ochronny musi być dopasowany do żądanego czasu użytkowania przy możliwie małych kosztach konserwacji lub renowacji,

- system ten musi być wykonany zgodnie z wymaganiami jakościowymi.

Wykonanie optymalnego systemu ochrony przed korozją wymaga odpowiedniego czasu i wcale niemałych nakładów. Inwestorzy i projektanci nie doceniają jednak często zarówno czasu jak i koniecznych kosztów.

Czas i miejsce wykonania ochrony musi być dokładnie zaplanowany i utrzymany. Spotykane często praktyki skracania czasu potrzebnego do prawidłowego wykonania systemu ochronnego, prowadzą jedynie do obniżenia jakości wykonywanego zabezpieczenia, a więc w efekcie do wzrostu kosztów eksploatacji obiektów. Z punktu widzenia przyszłego użytkownika niedopuszczalne jest więc poszukiwanie możliwości ograniczania nakładów na budowę określonej konstrukcji w zmniejszaniu kosztów jej ochrony przed korozją.

\section{Systemy ochronne}

W zasadzie omawiany system ochronny polega na nałożeniu na chronione powierzchnie odpowiednio dobranej powłoki:

- malarskiej,

- metalowej,

- metalowo-malarskiej.

Dobór rodzaju powłoki uzależniony jest od agresywności korozyjnej środowiska eksploatacji. Przyjęto w PN-EN ISO 12944, że agresywność ta określona jest roczną wielkością ubytku cynku lub stali (tabl. I). 
Tablica I. Klasyfikacja środowiska korozyjnego wg ISO 12944-2. Środowiska atmosferyczne Table I. Classification of corrosive environment in compliance with ISO 12944-2. Atmospheric ambience

\begin{tabular}{|c|c|c|c|c|c|c|}
\hline \multirow{3}{*}{$\begin{array}{l}\text { Kategoria } \\
\text { korozyjności }\end{array}$} & \multicolumn{4}{|c|}{$\begin{array}{l}\text { Ubytek masy na jednostkę powierzchni } \\
\text { i grubości po pierwszym roku ekspozycji }\end{array}$} & \multirow{2}{*}{\multicolumn{2}{|c|}{$\begin{array}{c}\text { Przykłady typowych środowisk } \\
\text { w klimacie umiarkowanym (dane informacyjne) } \\
\text { powierzchnie }\end{array}$}} \\
\hline & \multicolumn{2}{|c|}{ stal węglowa } & \multicolumn{2}{|c|}{ cynk } & & \\
\hline & $\mathrm{g} / \mathrm{m}^{2}$ & $\mu \mathrm{m}$ & $\mathrm{g} / \mathrm{m}^{2}$ & $\mu \mathrm{m}$ & zewnętrzne & wewnętrzne \\
\hline $\begin{array}{c}\mathrm{C} 1 \\
\text { bardzo słaba }\end{array}$ & $\leq 10$ & $\leq 1,3$ & $\leq 0,7$ & $\leq 0,1$ & - & $\begin{array}{l}\text { Wnętrza ogrzewanych budynków } \\
\text { z czystą atmosferą np. sklepy, } \\
\text { szkoły, hotele. }\end{array}$ \\
\hline $\begin{array}{c}\text { C2 } \\
\text { słaba }\end{array}$ & $>10-200$ & $>1,3-25$ & $>0,7-5$ & $>0,1-0,7$ & $\begin{array}{l}\text { Atmosfera z małą zawarto- } \\
\text { ścią zanieczyszczeń; głów- } \\
\text { nie tereny wiejskie. }\end{array}$ & $\begin{array}{l}\text { Budynki nieogrzewane z moż- } \\
\text { liwością kondensacji wilgoci } \\
\text { np. magazyny, hale sportowe. }\end{array}$ \\
\hline $\begin{array}{l}\text { C3 } \\
\text { średnia }\end{array}$ & $>200-400$ & $>25-50$ & $>5-15$ & $>0,7-2,1$ & $\begin{array}{l}\text { Atmosfera miejska i prze- } \\
\text { mysłowa, średnio zanie- } \\
\text { czyszczona } \mathrm{SO}_{2} \text {. Rejony } \\
\text { przybrzeżne o małym zaso- } \\
\text { leniu. }\end{array}$ & $\begin{array}{l}\text { Pomieszczenia produkcyjne o wy- } \\
\text { sokiej wilgotności i nieco zanie- } \\
\text { czyszczonym powietrzu np. pro- } \\
\text { dukcja środków spożywczych, } \\
\text { browary, pralnie, mleczarnie. }\end{array}$ \\
\hline $\begin{array}{c}\text { C4 } \\
\text { wysoka }\end{array}$ & $>400-650$ & $>50-80$ & $>15-30$ & $>2,1-4,2$ & $\begin{array}{l}\text { Rejony przemysłowe i nad- } \\
\text { morskie o średnim zasoleniu. }\end{array}$ & $\begin{array}{l}\text { Zakłady chemiczne, baseny, stat- } \\
\text { ki morskie i żeglugi przybrzeżnej. }\end{array}$ \\
\hline $\begin{array}{c}\text { C5-I } \\
\text { b. silna } \\
\text { (przemysł) }\end{array}$ & $>650-1500$ & $>80-200$ & $>30-60$ & $>4,2-8,4$ & $\begin{array}{l}\text { Rejony przemysłowe o wy- } \\
\text { sokiej wilgotności powietrza } \\
\text { i agresywnej atmosferze. }\end{array}$ & Budynki o permanentnej kc \\
\hline $\begin{array}{l}\text { C-5M } \\
\text { b. silna } \\
\text { (morska) }\end{array}$ & $>650-1500$ & $>80-200$ & $>30-60$ & $>4,2-8,4$ & $\begin{array}{l}\text { Zewnętrzne powierzchnie } \\
\text { statków i platform wiertni- } \\
\text { czych. }\end{array}$ & czyszczeniu powietrza. \\
\hline
\end{tabular}

Zgodnie z tą normą rozróżnia się trzy okresy trwałości systemu ochronnego:

krótki -2 do 5 lat

średni -5 do 15 lat

długi - powyżej 15 lat

Zgodnie z cytowaną normą okres trwałości oznacza czas eksploatacji do momentu wystąpienia na pokryciu punktów korozyjnych, obejmujących sumarycznie $1 \%$ powierzchni (Ri 3 wg PN-EN ISO 4628-3). Okres trwałości zależy od szeregu czynników, z których najistotniejsze to: rodzaj i grubość powłok ochronnych, korozyjność środowiska, kształt konstrukcji z punktu widzenia narażeń korozyjnych, stan wyjściowy podłoża, jakość przygotowania powierzchni, prawidłowa aplikacja farb. Nakłady rosną wraz z wydłużaniem okresu trwałości; należy znaleźć optymalną relację pomiędzy poniesionymi kosztami na zabezpieczenie przed korozją, kosztami budowy obiektu i zakładanym okresem jego eksploatacji.

Wieloletnie doświadczenie i wyniki prac badawczych jednoznacznie potwierdzają, że najbardziej trwałą ochronę przed korozją zapewniają powłoki metalowo-malarskie. W budownictwie mostowym i drogowym przewidywanym do wieloletniej eksploatacji, jedną z najbardziej istotnych spraw jest zapewnienie długoletniej ochrony konstrukcji dlatego w ostatnim 15-leciu obserwuje się intensywny rozwój badań mających na celu wykorzystanie niewątpliwej zalety powłoki metalowej np. cynkowej w postaci jej wysokiej odporności korozyjnej i jej ochraniających właściwości elektrochemicznych z coraz lepszymi właściwościami ochronnymi powłok malarskich, co razem pozwala na opracowanie systemu ochronnego bardziej ekonomicznego, wykorzystującego synergizm działania obu zastosowanych powłok.

Ochronne i elektrochemiczne działanie cynku w systemach ochrony przed korozją wykorzystywane jest nie tylko w wytwarzaniu powłok cynkowych lecz również przez dodanie pyłu cynkowego do materiału malarskiego. Tego rodzaju farby stosowane są jako materiały podkładowe, na które nakłada się następnie wybrane warstwy malarskie o żądanych właściwościach. Zgodnie z PN-EN ISO 12944-5 farby te stosowane są jako materiały podkładowe przy narażeniu konstrukcji na agresywność środowiska C3 lub C4. Jak jednak wynika z ostatnich badań laboratoryjnych firmy Hempel [10] tylko ok. 30\% cynku dodawanego do farb epoksydowych pełni rolę ochrony elektrochemicznej. Dlatego firma ta opracowała nowy rodzaj materiału gruntującego nazwanego HEMPADUR AvantGuard zapewniającego lepszą ochronę elektrochemiczną o zmniejszonej skłonności do pękania.

Wydaje się jednak bezspornym fakt, że tylko bezpośredni kontakt cynku z chronioną powierzchnią stalową zapewni optymalne wykorzystanie jego właściwości ochronnych.

Przy obecnym stanie techniki nakładania powłok metalowych na konstrukcje stalowe, z różnych metod nakładania takich powłok, możemy praktycznie wykorzystać tylko dwie:

- metodę zanurzeniową (ogniową), przy czym przy pokrywaniu indywidualnym możemy dzisiaj nakładać praktycznie tylko cynk, lub cynk z niewielkim dodatkiem innych pierwiastków takich jak Al, Ni, Bi, Sn i innych;

- metodę natryskiwania cieplnego umożliwiającą nakładanie powłok na dowolnie duże elementy z całego szeregu materiałów, przy czym do ochrony przed korozją wykorzystuje się przeważnie Zn, Al i ich stopy.

Biorąc pod uwagę roczny ubytek cynku przy agresywności środowiska C4 wielkości ok. $4 \mu \mathrm{m} / \mathrm{rok}$, to ogniowa powłoka cynkowa o grubości ok. $100 \mu \mathrm{m}$ będzie chroniła konstrukcję przez ok. 25 lat bez żadnych zabiegów renowacyjnych. Te założenia teoretyczne potwierdzają się $w$ praktyce [2].

Ze względu na wielkość i masę konstrukcji mostowych początek wykorzystania ogniowych powłok cynkowych ma miejsce dopiero w latach 70-tych ubiegłego stulecia.

I tak w 1974 r. w Wlk. Brytanii zastosowano cynkowanie ogniowe do ochrony przed korozją mostu w Cleveland. Kontrola przeprowadzona w latach 1979, 1989 i 1997 potwierdziły, że podczas 25 latach eksploatacji ubyło praktycznie $35 \mu \mathrm{m}$ powłoki. I z powłoki o wyjściowej grubości $150 \mu \mathrm{m}$ 
w najcieńszym miejscu pozostało $115 \mu \mathrm{m}$. Oznacza to, że przez co najmniej następne 25 lat powłoka nie będzie wymagała konserwacji.

W Japonii pierwsze podpory mostowe o długości $13 \mathrm{~m}$ ocynkowano ogniowo w 1963 r. Od roku 1970 nastąpiło intensywne wykorzystanie tej metody w budownictwie mostowym. Stwierdzono przy tym, że roczne ubytki powłoki Zn nie przekroczyły $1,87 \mu \mathrm{m}$ na rok, co oznacza trwałość powłoki o grubości $85 \mu \mathrm{m}$ równo 41 lat [3].

W Kanadzie podczas remontu i poszerzania mostu w Toronto w 1969 r. zastosowano trzy technologie:

- trzywarstwową powłokę malarską z gruntem wysokocynkowym,

- cynkowanie ogniowe nowych części a części oryginalne pokrywano powloką malarską,

- cynkowanie ogniowe nowych części i natryskiwanie cieplne części oryginalnych - starych.

Po 20 latach eksploatacji w 1989r. najbardziej trwałe okazało się rozwiązanie trzecie, które nie wymagało żadnych uzupełnień. Powłoka malarska musiała być uzupełniona w $1981 \mathrm{r}$.

Podobne wyniki odnotowuje się również w Niemczech i USA. Cynkowanie ogniowe jest nie tylko najbardziej trwałym sposobem zabezpieczenia przed korozją ale również najtańszym (tabl. II).

Drugą metodą umożliwiającą nałożenie powłoki metalo- wej jest natryskiwanie cieplne umożliwiające nałożenie powłoki na konstrukcje dowolnych wymiarów. Wykorzystanie natryskiwania cieplnego do ochrony konstrukcji mostowych i zapór wodnych rozpoczęto we Francji w latach 1920-28 i od tamtej pory następuje stały wzrost wykorzystania tej metody na świecie.

W Polsce pierwszy most na rzece Huczwie pometalizowano w 1957r. Od tamtej pory metodę tę zaczęto coraz szerzej stosować nie tylko w budownictwie mostowym lecz także w budownictwie wodnym, budowie statków, w przemyśle cukrowniczym i chemicznym (tabl. II).

Głównie stosuje się ją na te konstrukcje, które będą eksploatowane przez wiele lat, które narażone są na środowisko o dużej agresywności (C4-C5) i które ze względu na wymiary nie można pokryć ogniowo.

$\mathrm{Na}$ specjalną uwagę i podkreślenie zasługuje fakt, że z otrzymanych z terenu wiadomości żadna z pometalizowanych w Polsce konstrukcji mostowych, pomimo upływu w wielu przypadkach 20 lat, a jak w przypadku mostu na Huczwie i w Broku, przeszło 70 lat, nie wymagały dotychczas żadnych prac renowacyjnych. Koszty ich eksploatacji przez te wszystkie lata były równe, bądź bliskie zeru. Eksploatowane są nadal bez konieczności jakichkolwiek uzupełnień.

Podobnie wysokie trwałości powłok metalizacyjno-malarskich stwierdzono na mostach natryskiwanych cynkiem w wielu krajach (tabl. II).

Tablica II. Przykłady trwałości powłok metalizacyjnych wykonanych w różnych krajach [6]

Table II. Examples of durability of thermal sprayed coatings in different countries [6]

\begin{tabular}{|c|c|c|c|}
\hline Konstrukcja & System ochronny & Rok metalizacji & $\begin{array}{l}\text { Rok ostatniego } \\
\text { przeglądu }\end{array}$ \\
\hline Kaw River (USA) & $250 \mathrm{~mm} \mathrm{Zn}$ & 1936 & 1975 \\
\hline Ridge Avenue (USA) & $250 \mathrm{~mm} \mathrm{Zn}$ & 1938 & 1984 \\
\hline Menai Straits (WIk.B) & $\begin{array}{c}150 \mathrm{~mm} \mathrm{Zn}+3 \text { warstwy powłoki } \\
\text { malarskiej }\end{array}$ & 1938 & 1968 \\
\hline Southwest Trafficway (USA) & $250 \mathrm{~mm} \mathrm{Zn}$ & 1950 & 1975 \\
\hline Vilsund (Dania) & $\begin{array}{c}\text { 100-150 mm Zn + } 3 \text { warstwy powłoki } \\
\text { malarskiej }\end{array}$ & 1951 & 1974 \\
\hline Most kolejowy, rzeka Huczwa & 300 mm Zn & 1957 & \\
\hline Djupfjord (Norwegia) & $\begin{array}{c}150 \mathrm{~mm} \mathrm{Zn} \mathrm{+} 1 \text { warstwa powłoki } \\
\text { malarskiej }\end{array}$ & 1958 & 1970 \\
\hline Conway Arch (Wlk.B) & $\begin{array}{c}100 \mathrm{~mm} \mathrm{Zn} \mathrm{+} 1 \text { warstwa powłoki } \\
\text { malarskiej }\end{array}$ & 1959 & 1970 \\
\hline Pomnik Grunwaldzki (pola Grunwaldu) & $300 \mathrm{~mm} \mathrm{Zn}$ & 1960 & \\
\hline Forth Road (Wlk.B) & $\begin{array}{c}0,75 \mathrm{~mm} Z \mathrm{Zn}+3 \text { warstwy powłoki } \\
\text { malarskiej }\end{array}$ & 1961 & 1975 \\
\hline Maszt radiowy (Konstantynów) & $200 \mathrm{~mm} Z \mathrm{n}$ & 1974 & \\
\hline Pierre-Laporte (Kanada) & $\begin{array}{c}125 \mathrm{~mm} \mathrm{Zn} \mathrm{+} 2 \text { warstwy powłoki } \\
\text { malarskiej }\end{array}$ & 1977 & 1985 \\
\hline Zapora wodna, tunele, śluzy (Czorsztyn) & $300 \mathrm{~mm} \mathrm{Zn}$ & $1985-86$ & \\
\hline Most drogowy (Brok) & 200 mm Zn +mal. & 1992 & \\
\hline Most Mieszczański (Wrocław) & 200 mm Zn +mal. & $1992-94$ & \\
\hline Most Świętokrzyski (Warszawa) & 200 mm Zn +mal. & 1999 & \\
\hline Most Jana Pawła II (Gdańsk) & 200 mm Zn +mal. & 2000 & \\
\hline Most Siekierkowski (Warszawa) & 200 mm Zn +mal. & 2000 & \\
\hline $\begin{array}{c}\text { Węzeł drogowy i ST. Starzyńskiego } \\
\text { (Warszawa) }\end{array}$ & 150 mm Zn +mal. & 2007 & \\
\hline
\end{tabular}


Koszty te zależą oczywiście od przyjętego systemu ochronnego tj. m.in. od grubości nakładanej powłoki metalowej oraz ewentualnych kosztów nakładania dodatkowej powłoki malarskiej. Jednakże jak wynika z dostępnych danych literaturowych, w przypadku uwzględnienia faktycznych kosztów eksploatacji konstrukcji koszty tzw. życia konstrukcji są zawsze najniższe przy powłokach metalowomalarskich (tabl. III i IV).

Również symulacyjne obliczenia kosztów eksploatacji różnego rodzaju systemów ochronnych przeprowadzone w kraju dla hipotetycznego mostu o powierzchni $3000 \mathrm{~m}^{2}$ wykazały jednoznacznie ekonomiczne walory natryskiwanych cieplnie i malowanych powłok ochronnych (rys.1).

Dla wymaganej trwałości i określonych zagrożeń korozyjnych dobiera się zwykle system ochronny wg PN-EN ISO 12944-5 [11]. Dla długich okresów trwałości w normie tej zalecane są zestawy metalowo-malarskie, przy czym norma nie zawiera żadnych wytycznych dotyczących grubości powłoki metalowej. Zgodnie z tą normą okres trwałości oznacza czas eksploatacji do momentu wystąpienia na pokryciu produktów korozyjnych obejmujących sumarycznie 1\% powierzchni (Ri 3 wg PN-EN ISO 4628-3).

W normie PN-EN ISO 2063 [12] podano minimalną grubość metalowych powłok antykorozyjnych natryskiwanych

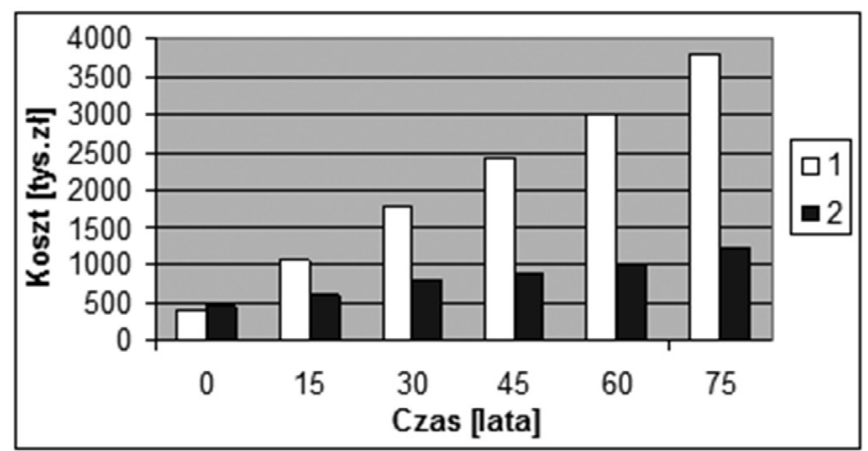

Rys. 1. Koszty wykonania i eksploatacji systemów ochronnych. 1 - system I: powłoka malarska - PSX (łatwy dostęp do powierzchni); 2 - system II: powłoka metalizacyjno-malarska /150 $\mu \mathrm{m} \mathrm{Zn}$ + $200 \mu \mathrm{m}$ EP + PU, (łatwy dostęp do powierzchni)

Fig. 1. Costs of manufacturing and exploitation of protective systems. 1- paint coating - PSX; 2 - metal-paints coatings $150 \mu \mathrm{m} \mathrm{Zn}$ $+200 \mu \mathrm{m} \mathrm{EP}+\mathrm{PU}$

cieplnie w zależności od agresywności środowiska (tabl. V).

Przy dokładnej analizie zalecanych w wyżej wymienionej tablicy grubościach powłok metalowych należy zwrócić uwagę na zasadniczy fakt, że podane wartości oczekiwanej

Tablica III. Porównanie kosztów cynkowania ogniowego z kosztami malowania [4]

Table III. Comparison of the hot-dip galvanizing and painting costs [4]

\begin{tabular}{|l|c|c|}
\hline \multicolumn{1}{|c|}{ Metoda } & Koszt nałożenia powłoki ${ }^{11}, \mathrm{z}^{\prime} \mathrm{f} / \mathrm{m}^{2}$ & Koszty eksploatacji na rok ${ }^{1)}, \mathrm{z}^{2} / \mathrm{m}^{2}$ \\
\hline Cynkowanie ogniowe & 30 & 0,99 \\
\hline $\begin{array}{l}\text { Powłoka malarska, podkład wysoko- } \\
\text { cynkowy + poliuretan }\end{array}$ & 50 & 4,95 \\
\hline
\end{tabular}

Tablica IV. Porównanie kosztów wykonania i eksploatacji różnych powłok ochronnych [8]

Table IV. Comparison of costs of implementation and operation of various protective coatings [8]

\begin{tabular}{|l|c|c|}
\hline \multicolumn{1}{|c|}{ Powłoka } & Koszt nałożenia powłoki ${ }^{1)}, \mathrm{z}^{\prime} / \mathrm{m}^{2}$ & Koszty eksploatacji na rok ${ }^{1)}, \mathrm{z}^{2} / \mathrm{m}^{2}$ \\
\hline Metalizacyjno-malarska & 129,3 & 4,71 \\
\hline Malarska trzywarstwowa & 84 & 9,42 \\
\hline Malarska dwuwarstwowa & 75 & 11,0 \\
\hline
\end{tabular}

Tablica V. Zalecane minimalne grubości dla różnych warunków stosowania (PN-EN ISO 2063)[12]

Table V. Minimum thicknesses recommended for different purposes (PN-EN ISO 2063)[12]

\begin{tabular}{|c|c|c|c|c|c|c|c|c|c|}
\hline \multirow{3}{*}{ Środowisko } & \multirow{3}{*}{$\begin{array}{c}\text { Klasyfikacja } \\
\text { środowisk } \\
\text { wg EN ISO } \\
12944-2\end{array}$} & \multicolumn{8}{|c|}{ Metal } \\
\hline & & \multicolumn{2}{|c|}{ Cynk } & \multicolumn{2}{|c|}{ Aluminium } & \multicolumn{2}{|c|}{ AlMg5 } & \multicolumn{2}{|c|}{ ZnAl15 } \\
\hline & & $\begin{array}{l}\text { niemalo- } \\
\text { wany }\end{array}$ & $\begin{array}{l}\text { malo- } \\
\text { wany }\end{array}$ & $\begin{array}{l}\text { niemalo- } \\
\text { wany }\end{array}$ & $\begin{array}{l}\text { malo- } \\
\text { wany }\end{array}$ & $\begin{array}{l}\text { niemalo- } \\
\text { wany }\end{array}$ & $\begin{array}{l}\text { malo- } \\
\text { wany }\end{array}$ & $\begin{array}{l}\text { niemalo- } \\
\text { wany }\end{array}$ & $\begin{array}{l}\text { malo- } \\
\text { wany }\end{array}$ \\
\hline Słona woda & $\operatorname{lm} 2$ & N.R. ${ }^{a}$ & 100 & 200 & 150 & $250^{\mathrm{b}}$ & $200^{\mathrm{b}}$ & N.R. ${ }^{a}$ & 100 \\
\hline Słodka woda & $\operatorname{Im} 3$ & 200 & 100 & 200 & 150 & 150 & 100 & 150 & 100 \\
\hline $\begin{array}{c}\text { Środowisko } \\
\text { wielkomiejskie }\end{array}$ & C2 i C3 & 100 & 50 & 150 & 100 & 150 & 100 & 100 & 50 \\
\hline $\begin{array}{l}\text { Środowisko } \\
\text { przemysłowe }\end{array}$ & C4 i C5-I & N.R. ${ }^{a}$ & 100 & 200 & 100 & 200 & 100 & 150 & 100 \\
\hline $\begin{array}{c}\text { Atmosfera } \\
\text { morska }\end{array}$ & C5-M & 150 & 100 & 200 & 100 & $250^{b}$ & $200^{b}$ & 150 & 100 \\
\hline $\begin{array}{l}\text { Sucha } \\
\text { atmosfera } \\
\text { domowa }\end{array}$ & $\mathrm{C} 1$ & 50 & 50 & 100 & 100 & 100 & 100 & 50 & 50 \\
\hline
\end{tabular}


trwałości dotyczą wyłącznie powłok metalowych zanurzeniowych lub natryskiwanych cieplnie względnie natryskanych i uszczelnionych.

W żadnej z norm (również PN-EN ISO 12944-5)[11] nie ma podanych trwałości po nałożeniu na powłokę metalową odpowiednio dobranej powłoki malarskiej. 0 trwałości takiego zestawu ochronnego decyduje głównie trwałość zewnętrznej powłoki malarskiej. Prawidłowo eksploatowany ochronny zestaw metalowo-malarski powinien być poddany renowacji po utraceniu przez powłokę malarską swojej roli dekoracyjno-estetycznej, czyli po degradacji powłoki malarskiej, ale przed wyraźnym pojawieniem się korozji materiału podłoża. W tym przypadku materiałem podłoża jest powłoka metalizacyjna, której celem jest dobre związanie z podłożem powłoki malarskiej i elektrochemiczna ochrona materiału podłoża przed działaniem korozyjnym środowiska po uszkodzeniu powłoki malarskiej do czasu jej renowacji. Żądanie więc od powłoki metalizacyjnej wieloletniej trwałości a więc zgodnej z tą trwałością grubości przewidzianej $w$ normie, jest $w$ tej sytuacji nieuzasadnione. Niecelowym jest więc natryskiwanie powłoki metalowej o takiej grubości jaka wymagana jest przy samodzielnej pracy powłoki metalowej. Wydaje się więc słusznym aby rozpatrując trwałość powłoki metalowo-malarskiej uwzględniać synergizm działania obu powłok. Należy więc sądzić, że jeśli stosowane są niemalowane powłoki zanurzeniowe lub tylko uszczelnione powłoki natryskiwane cieplnie to wtedy należy stosować grubość zalecana przez obie wspomniane normy. Przy stosowaniu systemu ochronnego składającego się z powłoki metalowej i nałożonej następnie dwu- lub trójwarstwowej powłoki malarskiej stosowanie grubych powłok metalowych wydaje się nieuzasadnione.

Przy takim założeniu obliczamy cykl życia konstrukcji przy powłokach metalowych o grubościach podobnych do gruntowych powłok malarskich z farb wysokocynowych byłby jeszcze bardziej korzystny.

Niestety obowiązujące przepisy krajowe $[13,14]$ zakładały, że minimalna grubość natryskiwanej powłoki cynkowej musi wynosić co najmniej $150 \mu \mathrm{m}$. Jednoznacznie trzeba stwierdzić, że są one sprzeczne z ustanowionymi normami krajowymi i europejskimi (PN-EN ISO 12944 i PN-EN ISO 2063). Przepisy krajowe wymuszają więc nieuzasadnione większe koszty wytwarzania powłok o najwyższej trwałości.

Obniżenie ogólnie stosowanych grubości powłok natryskiwanych cieplnie do grubości zgodnych z PN-EN ISO 2063 pozwoliłoby na istotne ograniczenie kosztów ich nakładania.

Dalsze znaczne ograniczenie omawianych kosztów można osiągnąć przy bardzo dokładnym przestrzeganiu prawidłowego procesu natryskiwania i stosowania nowoczesnego sprzętu zapewniającego istotne zmniejszenie strat materiału powłokowego.

Badania przeprowadzone w IMP [15] pozwoliły na stwierdzenie, że straty materiału powłokowego powstające podczas łukowego natryskiwania są m.in. zależne od:

- rodzaju układu rozpylania,

- odległości i kata natryskiwania,

- napięcia łuku.

Jak wynika z rysunkach $2 \div 5$ koszty te mogą przy nieprawidłowym prowadzeniu procesu wzrastać o $30 \%$.

Podczas badań przeprowadzonych w IMP z konstruowa-

Rys. 5. Wpływ odległości natryskiwania na koszt materiału powłokowego koniecznego do pokrycia $1 \mathrm{~m}^{2}$ powierzchni na grubość $100 \mu \mathrm{m}$ Fig. 5. Effect of spraying distance on the costs of material volume to cover surface of $1 \mathrm{~m}^{2}$ with $100 \mu \mathrm{m}$ coating thickness

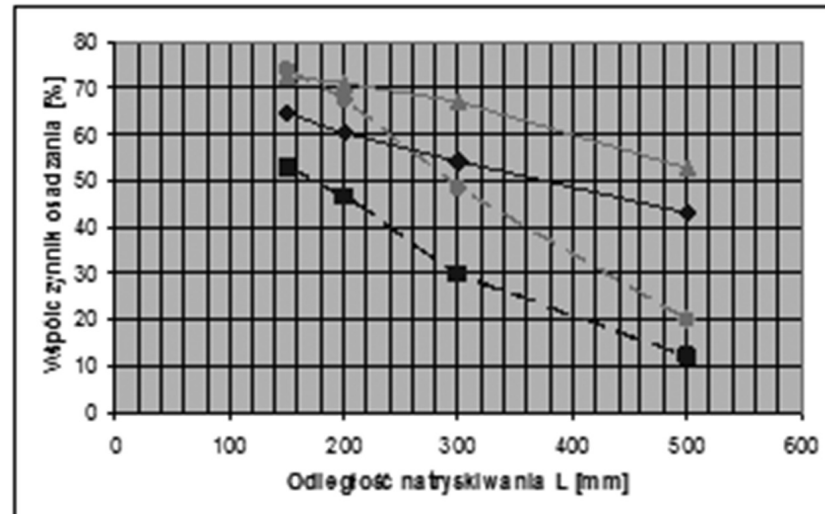

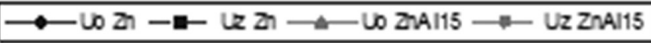

Rys. 2. Wpływ odległości natryskiwania na wartość współczynnika osadzania

Fig. 2. Effect of spraying distance on deposition efficiency

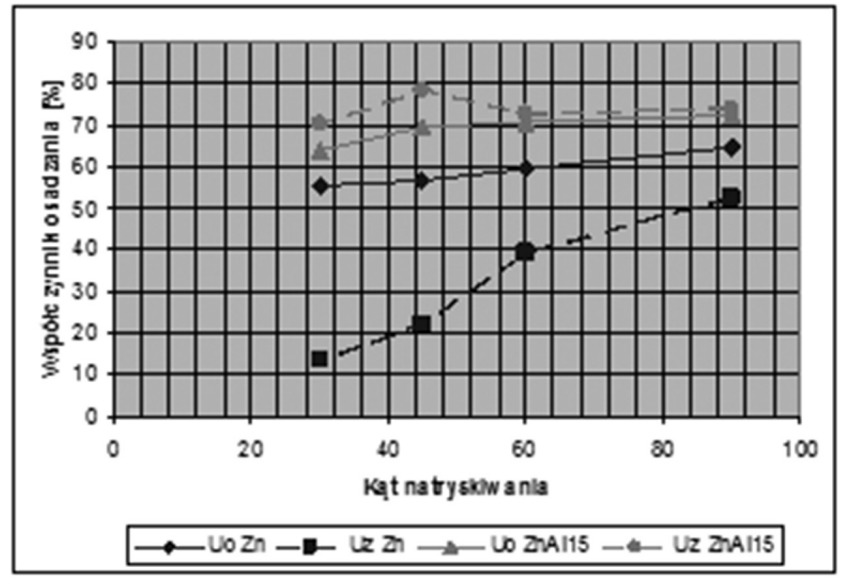

Rys. 3. Wpływ kąta natryskiwania na wartość współczynnika osadzania

Fig. 3. Effect of spraying angle on deposition efficiency

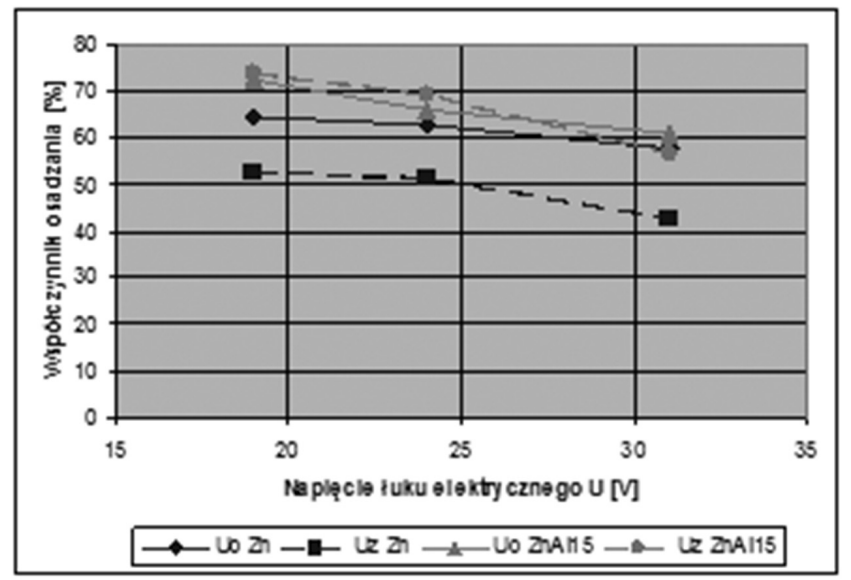

Rys. 4. Wpływ napięcia łuku na wartość współczynnika osadzania Fig. 4. Effect of arc voltage on deposition efficiency

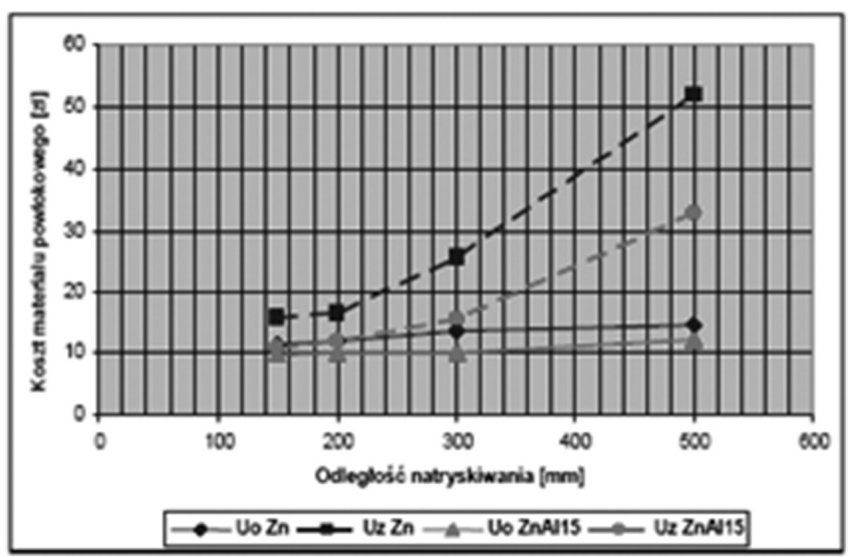


nymi obecnie w kraju nowoczesnymi pistoletami łukowymi stwierdzono, ze istnieje również możliwość dalszego obniżenia strat materiału powłokowego poprzez odpowiednie zmiany układu rozpylającego. Jak wynika z tablicy VI nowo- skonstruowany pistolet Metarc 555 umożliwia zmniejszenie strat materiału o $15 \%$.

Tablica VI. Wartości współczynnika osadzania powłok natryskanych cieplnie przy użyciu LD/U2 OSU, Metarc 555

Table VI. Values of deposition efficiency of coatings thermally sprayed with LD/U2 OSU, Metarc 555

\begin{tabular}{|l|c|c|c|}
\hline \multirow{2}{*}{ Rodzaj urządzenia } & \multicolumn{2}{|c|}{ Wartości współczynników osadzania [\%] } \\
\cline { 2 - 4 } & $200 \mathrm{~A}$ & $250 \mathrm{~A}$ & $400 \mathrm{~A}$ \\
\hline LD/U2 OSU & 52,73 & - & - \\
\hline Metarc 555 & 62,10 & 63,17 & 64,07 \\
\hline
\end{tabular}

\section{Wnioski}

1. Powłoki metalowo-malarskie odznaczają się b. dużą trwałością i tzw. niskimi kosztami cyklu życia.

2. Istniejące w kraju obowiązujące zalecenia i przepisy wymagają istotnej modernizacji gdyż nie uwzględniają ustanowionych w tym zakresie norm i doświadczeń krajowych i światowych.

3. Odpowiednia modernizacja przepisów umożliwi znaczne obniżenie kosztów nakładania powłok metalizacyjno-malarskich.

4. Na koszty wytwarzania powłok bardzo duży wpływ ma prawidłowy sposób natryskiwania a więc kwalifikacje personelu odpowiedzialnego za każdy etap powstawania systemu ochronnego.

5. Wzorem innych krajów konieczne jest szybkie wprowadzenie obowiązku certyfikowania personelu.

\section{Literatura}

[1] L.Kwiatkowski, W.Milewski: Powłoki metalowe w ochronie przed korozją konstrukcji stalowych. Informator Gospodarczy PIKS 2009.

[2] PN-EN ISO 14713-1:2010 Powłoki cynkowe - Wytyczne i zalecenia dotyczące ochrony przed korozją konstrukcji ze stopów żelaza - Część 1: Zasady ogólne dotyczące projektowania i odporności korozyjnej.

[3] Thermal Spray Coatings-Past, Present \& Future Ted Call - District Sales Manager KTA - Tator, Inc Pittsburgh, Pennsylvania, USA

[4] DOT Wirginia 6-02.5 (13) OPT3FB6 Corrosion Protection August 2010.

[5] Metallized coatings for corrosion control of naval ship structures and components. National Research Council (U.S.) National Materials Advisory Board. Washington, D.C.: National Academy Press, 1983.

[6] Karsten Mühlberg Corrosion Protection for Windmills Onshore and Offshore. Hempel (Germany Ltd. Cologne (Germany), August 2004.

[7] Phil Rahrig “Analyzing costs of galvanizing structural steel, Plant Engineering October 2004.

[8] A.H. Roebuck, G.H Brevoort, "Coating Works Costs: Computer Application and Inspection", CORROSION/86, National Association of Corrosion Engineers, Houston, Texas, 1986.
[9] W.Milewski, J.Kobus, A.Olbrycht: Koszt wykonania i eksploatacji powłok metalowych i metalowo-malarskich chroniących konstrukcje stalowe przed korozją. V Konferencja Naukowo-Techniczna PSK „Współczesne technologie przeciwkorozyjne", $2011 \mathrm{r}$.

[10] Nowe definicje antykorozji dzięki zastosowaniu aktywowanego cynku. Konstrukcje Stalowe Nr 2/2015 s

[11] PN-EN ISO 12944-5:2009 Farby i lakiery. Ochrona przed korozja konstrukcji stalowych za pomocą ochronnych systemów malarskich. Część 5: Ochronne systemy malarskie.

[12] PN-EN ISO 2063:2006 Natryskiwanie cieplne - Powłoki metalowe i inne nieorganiczne - Cynk, aluminium i ich stopy.

[13] Rozporządzenie Ministra Transportu i Gospodarki Morskiej z dnia 30.05.200 r. w sprawie warunków technicznych jakimi powinny odpowiadać drogowe obiekty inżynierskie i ich usytuowanie (Dz.U. 2000 r. $\mathrm{Nr}$ 63, poz. 735).

[14] Zalecenia do wykonywania i odbioru antykorozyjnych zabezpieczeń konstrukcji stalowych drogowych obiektów mostowych - nowelizacja w $2006 \mathrm{r}$.

[15] W.Milewski, A.Olbrycht., Sz.Pawlik: Wpływ parametrów natryskiwania na koszty procesu i odporność na korozję powłok natryskiwanych łukowo. Inżynieria Powierzchni Nr 4/2014, s. 31-37. 